\title{
(1⿶)
}

Citation:

Dowse, S and Fletcher, TE (2018) Sport mega-events, the non-West and the ethics of event hosting. Sport in Society, 21 (5). pp. 745-761. ISSN 1743-0437 DOI: https://doi.org/10.1080/17430437.2018.1401359

Link to Leeds Beckett Repository record:

https://eprints.leedsbeckett.ac.uk/id/eprint/3605/

Document Version:

Article (Accepted Version)

The aim of the Leeds Beckett Repository is to provide open access to our research, as required by funder policies and permitted by publishers and copyright law.

The Leeds Beckett repository holds a wide range of publications, each of which has been checked for copyright and the relevant embargo period has been applied by the Research Services team.

We operate on a standard take-down policy. If you are the author or publisher of an output and you would like it removed from the repository, please contact us and we will investigate on a case-by-case basis.

Each thesis in the repository has been cleared where necessary by the author for third party copyright. If you would like a thesis to be removed from the repository or believe there is an issue with copyright, please contact us on openaccess@leedsbeckett.ac.uk and we will investigate on a case-by-case basis. 


\section{Sport mega-events, the non-West and the ethics of event hosting}

Events and sports events are perceived as having the potential to contribute to a number of benefits for the host country and its communities. However, mega sports events in particular are also known for their darker side. These consequences flow from the scale and complexity of the event, and the logistics of delivering what is effectively a national mega-project. The socio-political and economic environment of the host is an important consideration for both prospective hosts and event owners when allocating hosting rights. It is therefore, unsurprising that concerns have been raised over the relatively recent relocation of events to developing countries which, by their nature, frequently lack the economic, political and social stability of the traditional industrialised host. Developing nations are less affluent and arguably less prepared to deliver large scale sports events than developed nations. Within developing contexts the cost of hosting and risk of failure is likely to be far higher than for events held in the developed world. Therefore, this paper asks, 'are governing bodies, when equipped with this knowledge, ethically obliged to withhold hosting rights from developing countries?' This paper argues that denying sovereign States the right to make their own decisions would appear to compound the low status of countries that mega-event hosting is perceived to address. It would also reinforce the positioning of countries as subordinate and subject to a form of neo-colonial control. Indeed, despite laudable claims, the primary interest of the event owners is the delivery of an event, meaning that considerations of individual national contexts are largely irrelevant to any award. The paper contends that event hosts - particularly those in the developing world - are potentially vulnerable to exploitation by the event owner.

Key words: Developing world; Ethics; FIFA; International Relations; Mega-sports event; West/Westernisation

\section{Introduction}

Events and sports events are perceived as having the potential to contribute to a number of benefits for the host country and its communities. Amongst other things these include: bringing lasting social and economic benefits, enhancing national identity and image, regeneration and place (re)development, as well as facilitating community cohesion and wellbeing (Sharpley and Stone, 2011). However, mega sports events (MSE) in particular are also known for their darker side. For example, they are frequently associated with corruption, soaring economic costs, environmental degradation, securitisation, gentrification, violence and human rights violations (Author B). More routinely, principally via media coverage, sports events remain a primary agonist in the (re)articulation of structural inequalities, along the lines of gender, sexuality, 'race' and ethnicity, social class, disability, and their intersections 
(Author B). Thus, according to Hayes and Karamichas (2012: 2) MSEs are not simply sporting or cultural phenomena:

They are also political and economic events, characterized by the generation and projection of symbolic meanings - most obviously over the nature of statehood, economic power and collective cultural identity - and by social conflict, especially over land use, and over the extent and contours of public spending commitments.

Without a doubt, MSEs have significant consequences for the host community. These consequences flow from the scale and complexity of the event, and the logistics of delivering what is effectively a national mega-project. They also result from the accompanying media attention that temporarily places the host in the global spotlight. MSE hosting opportunities are invariably presented as a means of attaining a range of social, political and economic benefits, particularly for the host communities, who customarily are the most directly impacted by delivery of such projects (Author A; Lindsay, 2014). While the socio-economic and political utility of these events has been appreciated for some time, the associated delivery processes also have an established history of raising social justice concerns (Adams and Piekarz, 2015; Butler and Aicher, 2015; Finkel, 2015; Brackenridge et al., 2013; Amnesty International, 2013; COHRE, 2007).1

The lack of effective processes to deal with concerns generated by MSE hosting processes is also evident in contemporary calls by social justice groups, like the Sports and Rights Alliance, for MSE owners to establish a human and social rights framework to protect and promote the interests of those impacted by event delivery processes. 2 Some positive progress has occurred, for example, the International Olympic Committee (IOC) has recently incorporated human rights principles in its Host City Contract, while The Fédération Internationale de Football Association (FIFA) has recognised the United Nations Guiding Principles on Business and Human Rights. 3 However, meaningful outcomes are yet to be identified and the sincerity of event owners to see past their own, predominantly financial, interests remains in doubt.

In part, this slow response could be attributed to the weaknesses in the current knowledge base informing public policy about the actual outcomes of these events, and what an adequate and effective response might entail. This gap is likely to be linked to the historical dominance of the economic justification for hosting which was frequently based on pre-event predictions, rarely followed up by post event evaluations (Coalter, 2012). Consequently, there is a great deal of information available on the economic potential of MSEs; much of which actually contests the positive claims made (Fedderson et al, 2009; de Nooij, et al, 2009). This is not to suggest that there is no support for the possibility of economic benefit (Gratton et al, 2001), but the overall message is that realising it is extremely challenging and will be especially difficult for some hosts. These challenges arise from the contextual sensitivity of event impacts and outcomes, which means that the socio-political and economic environment of the host is an important consideration when seeking to determine what these might be.

It is therefore, unsurprising that concerns have been raised over the relatively recent relocation of events to developing countries which, by their nature, frequently lack the economic, political and social stability of the traditional industrialised host (Matheson and 
Baade, 2004). This contextual difference is important as the absence of this stability, along with invariably lower levels of the organisational and physical infrastructure required for delivery, complicates the achievement of positive outcomes because it makes hosting far more expensive and resource intensive. The expected return on investment for these hosts is also questioned, particularly with respect to the associated infrastructure development and its longer-term social value. The recent media images of derelict Olympic stadia in Brazil are a case in point (The Guardian, 2017).

The prevalence of negative social outcomes for MSE projects has inevitably drawn attention to the ethical responsibilities of events owners who award their events on the basis of a competitive bidding process. This paper is concerned with exploring debates around whether it is ethically responsible for developing countries to be awarded hosting rights for MSEs when event owners know that, in these countries, community rights and interests are unlikely to have a well-functioning protective framework, public resources are insufficient for existing social priorities and, consequently, vulnerable communities are likely to be placed unnecessarily at risk. Conversely, why these areas seek to host in the first place, especially given the more limited potential for positive social and economic outcomes to be achieved, also needs extrapolating. Both of these questions need to be addressed in order to return to the ethical dilemma of whether, for example, developing countries ought to be protected from themselves by event owners through the act of withholding hosting rights. Because, perhaps, if the aims of these hosts can be understood and the reasons why they may or may not be delivered on are recognised, it will be possible to consider whether an ethically driven prohibition on hosting in developing country contexts is fair and justifiable or, whether an appropriate answer for ethical considerations might lay elsewhere.

\section{Sport events, Westernisation and the non-West}

Events are embedded within the socio-cultural milieus of their host communities. Many of the world's international sporting events, staged since the Second World War, have predominantly emerged and been hosted within Europe, North America, Japan and Australia. This is, in part, due to the success and growth within these post war nations' economies. These regions of the world, collectively known as the 'developed' or 'Western' world, have developed a series of value systems over what sport is, how and where it should be played and, more importantly to this paper, how and where their associated events ought to be hosted.

International sports governing bodies for the majority of 'major' sports, such as association football, cricket, rugby and tennis, were founded in Western nations and so were also loosely based around Western values. This provided the basis for the structural dominance evident today, as Gupta (2009: 1779) argues "Because Western nations were the founder members of most international sporting associations they dominated these bodies and set the rules for a sport, dominated its finances, and determined the location of major international events". This dominance notwithstanding, there is a clear trend towards many 'emerging' regions outside of the Western world hosting, and/or actively seeking to host, international sporting events (Author B). A result of which, as Little (1995) wrote, mega-events, 
Have brought the issues of world justice to the fore of an international political arena long dominated by the self-serving discourse of the world's major industrial powers. (Little, 1995: 265)

MSEs have been staged in non-Western countries for some time. For example: Tokyo Olympics, 1964; Mexico Olympics, 1968; Seoul Olympics, 1988; FIFA World Cup in Uruguay 1930, Brazil, 1950, Mexico 1986, Japan/South Korea, 2002, India, 2010, South Africa, 2010 and Brazil, 2014 and 2016. However, for many, the 2008 Beijing Olympic and Paralympic Games set in motion a new social and political agenda for considering the role of non-Western nations on the major international sports events circuit (Palmer, 2013). Russell and O'Connor (2013) suggest that the 'success' of Beijing has encouraged other non-Western nations/cities to announce to the IOC their credentials, willingness and readiness to 'bid' to be host cities for future Olympics. However, the current trend may reflect the development of events as a benchmark of development status because to host is considered 'normal practice' for States at a certain level of development. However, it appears possible that the current volume of events held annually means that they no longer easily perform the historical role as marker of distinction in the global marketplace of cities as perhaps they once did.

Indeed, emerging nations from Asia, South America and the Middle East are now actively seeking, and are being courted by event owners and organisers, to be potential future hosts and venues for all types of international sporting events; many of which attract global media audiences (Author B). Countries such as China (Beijing Olympics and Paralympics, 2008; India (Commonwealth Games 2010), Bahrain (Formula One - annual), Russia (UEFA Champions League Final, 2010) and Brazil (men's FIFA World Cup, 2014 and Olympic and Paralympic Games, 2016) have all recently staged major sporting events.

This global shift in the hosting of international sporting events outside of the West is set to continue. For example, the men's FIFA Football World Cup will be hosted by Russia in 2018 and Qatar in 2022 respectively. Bang (2011: 1) suggests that "the biggest events are leaving Europe and North America". Evidence of this shift can be provided by the Danish Institute for Sports Studies Research which predicts that only $23 \%$ of major international events, such as the Olympic and Paralympic Games and world championship tournaments in football, athletics and swimming, will be held within Western countries after 2010. The remaining $77 \%$ of these events will be held within countries from the Middle East, Asia, Africa (south of the Sahara Desert) and Central/South America (Bang, 2011).

This shifting pattern can be conceptualised through the idea of 'post-Westernisation' (Rumford, 2007). For Rumford this shift is not simply about the decreasing salience of the idea of the West as a reference point for political identification and global leadership, rather, it can be characterised through a series of processes. Firstly, he suggests that post-Westernisation signals the increasing "lack of unity within those countries formerly considered to have a common 'Western' world view" (p.205). Secondly, post-Westernisation signifies the coexistence of multiple 'modernities' - Western, post-communist, Islamic - as opposed to an assumed dominance of the West over the rest. Finally, post-Westernisation involves recognition of a 'new East' capable of "shaping global affairs previously seen as the preserve of the West" (p.206). 
Viewed through the lens of the relocation of MSE, the reality of post-Westernisation appears further away than it may actually seem because this development presents international sports organisations and their commercial sponsors with opportunities to make significant economic gains by, for example, accessing new markets, while the associated costs are borne by a host ill-equipped to bear them. The greatest irony to this relationship is that awarding the event to those developing contexts can be perceived as justice for the historically marginalised when it could equally be presented as an opaque tool of exploitation, which offers up scarce resources, and may additionally complicate social and economic development in these areas.

Ultimately, debate continues as to what benefit(s) the staging or hosting of a MSE can actually bring to a country or a city, especially one in the developing world. While it is frequently suggested that hosting opportunities will facilitate much needed social development within the host city/country, the counter position is that their utility is rather to project symbolically a message of parity to the international community. For example, Darnell (2012: 105) argues that, "sports mega-events ... are used to showcase successful development, particularly for States struggling for legitimacy within competitive globalisation".

Whilst mega-events clearly present opportunities for development, crucially, the ways in which rights to host are contested, how they are allocated and subsequently, how they are expected to be delivered, are judged according to Western standards. For Hayes and Karamichas (2012: 6), such Western-centrism raises the question of homogenisation and cultural standardisation, or "rather the projection of a Western, liberal model of social relations on local host communities". This begs the question of whether we are in fact witnessing a shifting locus of power after all. That MSE are being hosted in developing countries with greater frequency is indisputable, however it remains the case that MSE are surrounded by Western logics over their production and delivery which, in many ways, reaffirms, rather than challenges, Western hegemony.

\section{Ethical concerns for the impacts of hosting}

The general destablisation of the economic case for hosting MSEs has prompted greater attention on the non-economic opportunities presented by event initiatives, regardless of who the aspirant host is (Chalip, 2006; Maennig \& Porche, 2008). Within or alongside this there has also been a noticeable rise in the attention given to the social cost of delivering an event which hitherto received relatively little attention. For example, research commissioned to inform a joint Dutch - Belgium bid for the 2018 and 2022 men's FIFA Football World Cups drew attention to the absence of a comprehensive and evidence-based approach to evaluating the implications of hosting, particularly with respect to social costs (de Nooij et al., 2010). This gap suggests that there are a number of governments that have pursued such 'opportunities' without the knowledge required to understand how the event will impact their communities.

Developments in media technology mean that it is now difficult to ignore or conceal the social impacts of hosting projects. In recent years there have been numerous reports and media footage of harm linked to event delivery processes and associated protest (Broudehoux, 2012; 
Lamond and Spracklen, 2014). It is also possible that the enhanced profile of these issues is a feature of the relocation of mega-events to developing countries. Here, the capacity to absorb the effects of event delivery emerge into sharper focus because, for example, the infrastructure development often perceived as causing the diversion of scarce public funding away from social priorities is likely to have more limited social value and the effects of such diversion more obvious. In such circumstances the MSE becomes the focus for displays of public protest as was witnessed in Brazil in the preparation periods leading to the 2014 men's FIFA Football World Cup and the 2016 Olympic and Paralympic Games (Butler and Aicher, 2015).

Growing alongside (and possibly as a consequence of) the increased profile of the negative impacts of event hosting is a growing demand for public influence in the decision to pursue an award. This is evident in the use of referendums to determine whether bid ambitions carry popular support and the results of referendums held in Krakow (2014), Boston (2015) and Hamburg (2015) confirm that this is not guaranteed. However, while civic engagement in the decision-making process is encouraging, it is not clear that the ability to influence relevant decision-making processes extends into the event preparation period if the event is awarded. What is clear is that momentum is growing for both event owners and governments to be made accountable for the impacts of hosting and also for the degree to which outcomes match the promises made (Author A; Cornelissen, 2012).

Given the high profile problems associated with MSEs, is it fair to suggest that aspirant hosts are aware that these initiatives carry a range of risks. What is less clear is how far those in the related political and policy making circles are aware of the true nature of the event potential in terms of the goals that are realisable and how they might be realised. It is important therefore, that any decision towards hosting is well informed. Research into the 2010 men's FIFA Football World Cup suggests that knowledge concerning very fundamental issues, such as how delivering the event in line with the event owner's wishes and the terms and conditions agreed through the contractual process, would constrain activity to achieve local policy goals varied tremendously across many relevant decision-making networks (Author A). It was equally true that very specific political and international relations goals existed and it appeared likely that even if at national level there was complete knowledge of these constraints, these drivers would have outweighed such considerations. While as a case study it would be inappropriate to generalise the findings of the South African experience to all developing contexts, key aspects of these findings are offered for consideration.

\section{Understanding the political support for the $\mathbf{2 0 1 0}$ men's FIFA Football World Cup hosting project}

One of the key features of South Africa's policy ambitions for the 2010 men's FIFA Football World Cup was the foreign policy goal of improving the country's status and position with the international and regional political elite. An important dimension of this expectation was that hosting would improve the ability to pursue and defend national objectives and interests in the future. In part, this expectation was grounded in the belief that the event would convey the symbolic message that the country and, by association, continent, had achieved globally 
recognised standards of development and deserved to be taken seriously in/by the international community.

This expectation has to be understood in relation to the positioning of developing countries within the international community as subordinate to developed industrialised nations. It also has to be understood in relation to South Africa's unfortunate historical legacy of apartheid which has weakened the country's regional standing and which continues to constrain its ability to pursue regional leadership ambitions (Adebajo, Adedeji \& Landsberg, 2007). This ambition was clearly set out by former President, Thabo Mbeki, in a State of the Nation address:

In the next few months South Africa will launch its bid to host the 2010 Soccer World Cup. Government wishes to assure our Soccer World Cup Bid Committee of our fullest support. ... We are certain of victory this time around, a victory that will be for all Africa ... as African's to host the Cricket World Cup, like the President's Golf Cup later this year, communicates the message that we are not wrong when we said that this, the $21^{\text {st }}$ century, will be an African Century. (South Africa: The Presidency, 2003a)

The ambition was also re-stated by then Deputy President, Jacob Zuma, at the handover of the bid book:

Africa clearly continues to move away from the fringes, and is asserting her rightful place among other regions of the world ... in 2010, Africa will take the stage and rightly so give the positive developments already in place in the continent ... It is very important that all should realize that the time has come for Africa to play its part. (South Africa: The Presidency, 2003b)

The underlying message in these statements was that South Africa and Africa, as political entities, are set on the outskirts of the international community and do not enjoy a parity of recognition as a consequence. They also confirm that the South African government perceived the hosting initiative as an opportunity to enhance both status and role as a means of developing from its peripheral status on a global stage. This suggests that in order to evaluate the ethical considerations of hosting projects, attention should be paid to exploring the basis and legitimacy of such beliefs and, moreover, whether hosting projects may be an effective means of addressing the challenges observed. To understand this further, we must acknowledge the role of the State in event hosting.

In terms of International Relations theory the State is recognised as the principal actor within the international community and conceptually, as an ideal, exists as a political authority arranged as a constitutionally independent government over a defined territory and settled population (Spears, 2004; Lake, 2008). Only the government holds the legitimate right to use force and this right derives from the responsibility held for maintaining internal order and protecting from external threat with the purpose of safeguarding society and facilitating social development (Jackson, 1990). The State is, therefore, expected to be an effective service and security provider that is capable of exercising control over the population and over institutions for the distribution of wealth. For this reason, these attributes are linked to perceptions of capacity, legitimacy and citizen's identification (Van de Walle \& Scott, 2011). By virtue of 
constitutional independence, the State is a sovereign entity, which has no internal equal or external superior. The government alone holds the authority to define and implement domestic laws and policies and those which govern foreign engagement and the limitations on the extent of its own authority.

The historically recognised overarching power configuration within the international community is invariably described as being between the developed North and developing South, the First and Third World or West and non-West (Gupta, 2009). Understanding where a State is located in this classification is important because to be defined as Southern, developing, Third World or non-Western, like those States in Latin America or Africa, reflects a position of subordination in relation to Northern, developed, First World or Western States like the United States of America and the United Kingdom. The basis of this positioning is not theoretical. The North/South, First/Third, developed/developing, West/non-West divide is grounded in a history of colonial or imperial domination and, more recently, the emergence of new States through, for example, the territorial break up of Eastern Europe. The importance of this history is that it has enabled 'developed' States to establish extensive access to, and influence on, the key resource channels in the global economy which underpin and enable them to maintain their hegemonic position. In essence, newer States have joined an established system with a recognised right to equality, but on the basis of disadvantageous power relations, which undermines this equality in practice. For this reason, improving the capacity for new and developing States to access and influence the 'core' is a frequent foreign policy concern because until this happens, and greater parity is recognised, they will remain marginalised on the periphery or semi-periphery of international relations (Schwengel, 2008).

Understanding the different dimensions of sovereignty, international structures of power relations, access to resources and perceptions of status, reputation, capacity and legitimacy are all important when thinking about the engagement of developing or newly emerged powers with MSEs. In addition to the event 'product', these events are hugely symbolic undertakings which are perceived to convey messages of national identity, legitimacy and capability to a domestic and foreign audience. Sports events often act as a focus for nationalist sentiments, providing citizens with opportunities to come together in a visible, collective expression of 'who we are', in opposition to an equally important, but denigrated 'who we are not' (Whigham, 2013). Such expressions of collective identity and togetherness are relatively rare in modern societies, and so sports events can be powerful symbols of nationhood and unity in people's otherwise fragmented lives (Author B). This symbolic value can often overshadow their financial implications. With this in mind, the irrationality of investment in an event with limited potential for a substantive economic return can be considered rather rational, especially in countries with weak or limited international profile and influence or with deeply divided societies, or a history of internal division and conflict.

The variable outcomes of MSEs with respect to economic and social development, image and reputation highlights that hosting initiatives are a possible poisoned chalice. Whether a State (developing or otherwise) should host a MSE is a legitimate question and the answer to this question ought to be made on the basis of an informed understanding of the ways in which their individual context will be impacted by the delivery processes associated with the event, as well as, the goals sought. For this responsible approach to move forward there has to be 
more clarity/honesty from the hosts about the goals themselves, especially because promoted, perceived and actual goals are not necessarily the same thing. This is clear in research into the economic dimensions of hosting initiatives, which shows that, not only is it hard to achieve an economic return on investment, but also that the key policy makers are likely to be aware that this is the case (Horne, 2004; de Nooij et al, 2010). This suggests that economic concerns have not been the primary motivation for these hosts and that policy statements are used primarily to gain the necessary public support to pursue hosting opportunities. For these more socio-cultural dimensions, the core question of whether MSES can and do offer States a return on investment, which balances the associated risk and costs, remains as salient as it is for the economic dimension. However, evaluating the wisdom of policy decisions grounded in these objectives is infinitely harder than evaluating economic dimensions. This may be the reason why there are fewer studies in this area and consequently, less empirical evidence of the outcomes gained.

What is known about the potential for image and reputation based dividends is that, like economic, the opportunities are primarily grounded in the ability to capture global attention and elevate popular interest in the host nation. This potential is identified in the pre-event and post-event phases as well as games-time. Through this, MSEs are expected to help States develop, or consolidate, a 'brand' (Sturm, 2015). The perceived 'brand' of a country is important, for as previously discussed, the power and status of a State is influenced by how it is perceived and understood by others, and this will be informed by the views and stereotypes held about it. Mega-events can support positive image and reputation development because they offer opportunities to project positive imagery. Moreover, in those instances where a State is attempting to overturn negative perceptions, event hosting can help demonstrate distance travelled from 'then' through to 'now'. The South Korean government displayed this political ambition through the 2002 men's FIFA Football World Cup which was expected to help the country 'rebrand itself as a leading economy after the Asian economic crisis of the late 1990s' (Horne, 2004: 1244).

While the successful delivery of a MSE that meets and reflects global standards of development certainly ought to enhance the reputation and image of the host, the positive potential in this area may be less than anticipated. This disjoint reflects the difficulties inherent in changing established perceptions and underpins the need for strategic and longterm investment in image and reputation development. Consequently, MSEs are only likely to be effective as a tool of image and reputation change if they are used as part of a broader nation-branding strategy. Indeed, evidence suggests that image and reputation change is unlikely to occur if the event is the focus of a temporary marketing campaign (Anholt, 2011). In addition, event-led makeovers are also problematic as they risk exposing the host to unhelpful media projections that reinforce negative stereotypes or may focus attention on political activity and social situations that may compromise positive reputations (Dimeo \& Kay, 2004; Finlay \& Xin, 2010; Palmer, 2013). Problems in the event delivery process are also likely to receive extensive coverage which may compromise the positive images hosts seek to convey. For example, media reports of the 2010 Commonwealth Games in New Delhi which documented unsanitary living conditions and infrastructure failures, like the collapse of a pedestrian bridge were invariably unaligned to the image the hosts sought to project (Curi et al., 2011). 
Anticipated positive outcomes, with respect to image and reputational change may be difficult to achieve because media coverage tends to rely on imagery and narratives that are informed by and reinforce existing stereotypes (Darcy, 2003; Dimeo \& Kay, 2004). This implies that the positive marketing potential of events is likely to be lower for countries that are associated with negative stereotypes and, in turn, are also in greatest need of re-imaging support (Ibid). In the main, these countries are likely to be the more newly established and which do not currently possess the levels of political, social and economic stability of their peers, thus identifying them as different and potentially less valuable. As a result, Dimeo and Kay (2004) suggest that developing countries and former colonies have less capacity to control media discourses, and are additionally challenged by the need to counter the use of colonial terms of reference and stereotypes in media reports. Darnell (2014: 1000) supports this position and suggests that popular representations of sport and events "can serve to secure the innocence and benevolence of global sport for Western audiences while insulating them from, and therefore solidifying, the political economy of unequal development."

However, any attempts to make sweeping generalisations about the hosting capacity of developing nations are not advised because developed nations are by no means insulated from negative and potentially damaging media coverage. For example, a comparative analysis of the coverage of the 2006 and 2010 men's FIFA Football World Cups held in Germany and South Africa respectively, found that the tone of reporting was remarkably similar, despite the fact that Germany is a developed country and not a former colony, while South Africa is a developing economy with a history of colonial control (Media Tenor, 2010). Interviews carried out with reporters as part of the study into the South African experience explored this feature of the findings and feedback received suggested a level of benevolence in reporting of the 2010 event which may have reflected a general consensus to recognise the additional challenges faced by South Africa. 4 It was additionally suggested that this benevolent approach was not witnessed in the case of Germany and would be unlikely for future developed country hosts. However, interpreting this as wholly positive for South Africa as it appears prima facie would be ill-advised. Indeed, such an approach from the media arguably does little to challenge Orientalist discourses surrounding the backwardness and organisational inefficiencies of developing nations and, as such, could have the opposite effect of reinforcing neo-colonial rhetoric of Western paternal dominance and superiority. Ultimately, this means that while event-hosting may support positive image development as part of a wider programme of image improvement there are significant risks involved; risks that political stakeholders may neither fully appreciate nor have the capacity to manage.

Within the domestic polity, events are perceived as capable of supporting the consolidation of political legitimacy because locating an event in a country signals that the host has been recognised as the legitimate territorially bound political authority (Levermore, 2004).5 This is important because external recognition confers legitimacy on claims to statehood and this recognition may have internal significance because they provide positive collective 'moments' that can foster sentiments of unity across divided domestic populations. The 1995 men's Rugby World Cup in South Africa illustrates these possibilities and is well-known for a perceived nation-building effect. However, despite receiving plaudits for this nation-building impact, how meaningful the effect was is debated and the associated discussions question whether the collective euphoria identified should be interpreted as social cohesion or as a 
temporary display of positive emotions inflated by the media and emotional heat of the event (Grundlingh, 1998; Hendricks, 2008).

Core to the concerns about the nation-building potential of sport events is that the organisers are primarily concerned with event delivery and not necessarily the social problems that exist internally. Moreover, rather than alleviating these problems, sports events may risk exacerbating social divides by emphasising existing inequalities and diverting resources from other social priorities (Hylton \& Morpeth, 2012; Butler and Aicher, 2015). The pressures created by hosting an event like, the fixed deadline for delivery, can result in the suppression of civil rights and undermine the perceived legitimacy of the host government. There are examples of suppression in established democratic sSates, including Australia and the UK (Nauright, 2004; Lindsay, 2014), which makes the trend for events to be hosted more regularly in non-established democracies and emerging States like Russia, Qatar and South Africa (where civil rights are inconsistently enjoyed or protected) particularly worrying.

MSEs are globally popular commercial spectacles that offer numerous opportunities to advance political ambitions. Although marketed on the basis of their economic potential, weaknesses in the economic evidence base suggests that broader socio-political dimensions are more influential motivators of political support. Problematically, information regarding the actual impact of MSEs in terms of nation-building, and the social outcomes that lie below, is sparse. In part, this is because there are few agreed proxies for measuring such impacts and those that are recognised tend to be temporary. Moreover, these non-economic drivers are obfuscated by the need to justify the public expenditure involved, particularly as positive 'intangible' outcomes are difficult to demonstrate and quantify. This does not mean that they are unrealisable. MSEs have a potentially unique capacity to capture global attention and elevate popular interest in a country over a sustained period of time. In the context of national interests, defined in terms of enhanced foreign and domestic policy capacity, the political opportunities hosting presents are extensive and broad-ranging. For these reasons, events are attractive policy options for all countries, but potentially more so for the political elite in contexts where domestic structures and capacities require development and where international influence or commercial engagement is weak. These are certainly characteristics of the developing country hosts that are now competing successfully to secure hosting rights.

This raises the possibility that, rather than the opportunity to gain specific benefits linked to the event, the contemporary demand for hosting rights in developing country contexts is a consequence of political developments in international relations. These developments include a shift in political and economic power away from the global North or 'West' and demands for greater equality of opportunity and parity of status by emerging economies. Explored through this perspective, it is possible that hosting ambitions are located within a broad and overarching political ambition to re-define relations in the international community and, in so doing, gain access to the political and economic opportunities held by those occupying the 'core' (those traditionally described as the 'West') of international relations.

Event owners are amenable to this development because a shift in location offers a valuable opportunity to access new and developing consumer markets on a proportionately low risk basis (Author B). Indeed the potential return from an emerging country host could be extensive, particularly if organisational inexperience in the management of mega-projects and 
weaknesses in governmental structures increase vulnerability to exploitation through, for example, disadvantageous contracting processes (Author A). However, it could also be argued that the relocation of events to developing countries offers opportunities to maintain existing power structures of dominance by the core over the periphery by providing access to political and economic resources under the guise of 'justice' for development.

\section{What then are the ethical questions?}

The formal sovereignty of States within the international community renders a universal exclusion of certain polities from the global competition inappropriate. Such prohibition would be discriminatory, while at the same time deny these countries the opportunity to explore alternative means of addressing domestic and foreign policy concerns - and particularly those that reflect the structural disadvantages of the international community. It would also reinforce the positioning of countries as subordinate and subject to a form of neocolonial control.

However, this is not to suggest that the processes currently in place for awarding events could not be improved or that the policy decisions made by political leaders with respect to MSEs are necessarily well-informed. It is reasonably safe to assume that international sport governing bodies like FIFA and the IOC welcome the move of events to developing country contexts, not only for altruistic ideals of sharing opportunities, but also for the commercial opportunities presented in terms of accessing new markets. Research by Author A into the South African experience also suggests that this relationship can be tainted by the perception that the governing body is exploiting their host's weaknesses in ways that reflect the disadvantages experienced as a result of their subordinate position within the international community generally. This exploitative side of the relationship may not be immediately apparent. For example, initially, FIFA's introduction in 2000 of the policy of rotation and the award of the event to South Africa was positioned by the government as justice gained for a continent historically marginalised by the international community. 6 However, as the process of delivery unfolded it appeared that, rather than justice, the event became a mechanism for paternal exploitation by FIFA. Much of this was linked to the contractual obligations associated with the event which were poorly understood initially, and which had debilitating implications. It also appeared that political sensitivities to perceptions of incompetence and the desire for international approval weakened South Africa's negotiating position in relation to FIFA, with the net effect being a compression of the ability to achieve foreign and domestic policy priorities, whether directly associated with the event or not. The case of South Africa is but one example that clearly illustrates the complexities involved in hosting MSEs; complexities that, evidence suggests, are exacerbated when considered in developing contexts.

How we manage the demands and expectations of governing bodies and event owners with the host project is an important area within event studies that has not generally received a great deal of attention. If we centralise ethics as an event host consideration, this is a significant omission. Indeed, that we know very little about the relationships between hosts and key stakeholders raises a number of ethical issues regarding how governments may lose 
control of the parameters of event delivery in ways that compromise the outcomes sought through the hosting initiative. It may also be the case, as we have suggested for the men's FIFA Football World Cup in South Africa, that international sports organisations may gain power, albeit temporarily, within a sovereign nation State through the hosting process in ways that could be considered comparable to that held by another sovereign State with greater power resources. More generally, these considerations bring to light the possibility that States new to hosting global mega-events have very limited understanding of what they are getting involved in and, as a result, might be seduced by what become unrealisable opportunities, much to the detriment of local communities' everyday lives. Such a situation may derive from a governing body's control of the management processes associated with the event and an historical lack of inter-State knowledge exchange. The ability to assert such dominance with little resistance from the host might be reflective of a lack of State-confidence to negotiate with a body that effectively holds the keys to Pandora's Box and the opportunities therein.

\section{Conclusion}

Given the significant financial investment required to successfully host a MSE, it is absolutely essential that all parties involved in the process sufficiently understand and appreciate the opportunities and pitfalls associated. We know that, by their very nature, developing nations are less affluent and arguably less prepared to deliver large scale sports events than developed nations. Within developing contexts the cost of hosting and risk of failing to achieve sought outcomes is likely to be far higher than for events held in the developed world. Therefore, it is appropriate to ask, 'are governing bodies, when equipped with this knowledge, ethically obliged to withhold hosting rights from developing countries?'

Some might argue that this is the responsible thing to do. Palmer (2013) reasserts that a major challenge facing organisers in developing contexts is ensuring that they do not fall victim to Global North/First World/developed/Western perceptions that they are boxing above their weight. In other words, they must ensure they succeed - otherwise they will reinforce the perception that they are not developed enough to host an event of such magnitude. The failure of one event has a influential demonstration effect for other developing nations. Palmer suggests there is an element of 'I told you so' amongst developed nations when developing nations either struggle or fail. She warns that the obvious solution for avoiding such a situation is for developing nations to invest disproportionately in the event. For example, the original budget for the 2010 Commonwealth Games in New Delhi was US\$1.3 billion. This was reported to have mushroomed to US\$15 billion, which was seven times more expensive than Melbourne in 2006, leading Majumdar and Mehta (2010) to describe the event as "by far and away the most expensive games in history" (cited in Palmer, 2013: 116). Palmer goes on to argue that this is because there is a tendency amongst developing nations to, not only aim to equal the achievements of their developed counterparts, they wish to outdo them. Given that success is invariably judged in relation to previous hosts' performances it is likely that all hosts seek to outdo their predecessor, whether they are developed or not, but the implications of exceeding the delivery capabilities of a developed country has far deeper resource implications; especially for countries which are starting from a lower level. 
This notwithstanding, denying sovereign States the right to make their own decisions would appear to compound the low status of countries that MSE hosting is perceived to address. For this reason, it seems sensible to suggest that a more appropriate response to the ethical dilemma of hosting rights is not to withhold them from states at lower levels of development, but rather to support them meet their goals and protect national interests. This would involve: 1) improving understanding of the policy outcomes sought and why; 2) raising awareness of the problems that could arise in achieving these outcomes; 3 ) more effectively managing the demands that event owners and governing bodies place on hosts. The bigger question here is who should be responsible for this?

Developing countries are on the periphery of the international community and are frequently subjugated. Mega-event hosting offers an opportunity to gain recognition from and access to the developed world, if only symbolically. Given that events have historically been hosted by developed countries, much of what is known reflects delivery in developed country contexts which, by association, reflects the world view of the specific developed country and its global position. Given the substantial difference a simple transfer of lessons learned and resultant expectations from the developed country experience is inappropriate in ways that parallel debates concerning 'universal' and 'relative' approaches to human rights and the standards and policies designed to achieve them (Bentley, 2005).

Further, there is also the issue that despite laudable claims, the primary interest of the event owners is the delivery of an event. It remains the case that hosts - particularly those in the developing world - are potentially vulnerable to exploitation by the event owner. Ultimately though, any associated social and political impacts to the hosts remain the host's responsibility. The point is not to suggest that this obviates the duty to protect citizens or that the capacity and priority for doing so should not be a fundamental piece of the award criteria. However, this is a qualitatively different consideration to the question of whether the capacity to make that decision should be denied to them based on an external evaluation of their capacity to meet externally determined judgments on social impact thresholds which appears, prima facie, to be denying an opportunity for sovereign decision making.

It seems reasonable to suggest that, due to the imperatives of global sport and the need to attract new audiences and investors, there is a need to expand sporting events into hitherto uncharted territories. This will require a reconsideration of many of the hegemonic ideological assumptions around which international sports events are currently conceptualised (Author B). Palmer (2013) argues that a central feature of global sports events policy is the Westernisation of cultural mores and values in non-Western host cities. The 2010 men's FIFA Football World Cup acts as a case in point. Author A argues that throughout South Africa's journey to host the event, the imperative to satisfy FIFA's various contractual demands regarding financing and infrastructure, amongst many others, created a situation in which national and local interests were highly vulnerable to those of the event. The subordination of national interests to accommodate mega-event prerogatives is significant because the rhetoric surrounding MSEs is that they will act as a catalyst for much needed social improvements.

We acknowledge that the content of this paper is preliminary. Our intention was not necessarily to provide answers to our observations. Rather, our intention was to provoke 
others to engage in work on this topic. At the very least, our aim was to shed light on some of the back stage, anticipatory concerns that surround hosting MSEs in developing or nonWestern contexts. In so doing, we hope these are now front stage and will be interrogated further.

\section{References}

Adams, A. \& Piekarz, M. (2015) Sport tourism and human rights: Positive or negative erosion? Journal of Policy Research in Tourism, Leisure and Events, 10: 1-17.

Adebajo, A., Adedeji, A., \& Landsberg, C. (2007) Introduction. In Adebajo, A., Adedeji, A., \& Landsberg, C. (eds) South Africa in Africa: the post-apartheid era. Scottsville: University of KwaZulu-Natal Press: pp.17-39.

Amnesty International. (2013) The dark side of migration: Spotlight on Qatar's construction sector ahead of the World Cup. London: Amnesty International.

Anholt, S. (2011) Beyond the nation brand: The role of image and identity in international relations. Exchange, 2: 6-12.

Bang, S. (2011). Western countries are losing the race for major sporting events [Online] Available from http://www. playthegame.org/news/detailed/western-countries-are-losingthe-race-for-major-sporting-events-5156.html [Accessed May 7, 2013].

Bentley, K.A. (2005) Can there be any universal children's rights? International Journal of Human Rights, 9(1): 107-123.

Brackenridge, C., Palmer-Felgate, S., Rhind, D., Hills, L., Kay, T., Tiivas, L., Faulkner, L., and Lindsay, I. (2013) Child exploitation and the FIFA World Cup: A review of risks and protective interventions. Brunel: Brunel Centre for Sport, Health and Wellbeing.

Broudehoux, A. (2012) Civilizing Beijing: Social beautification, civility and citizenship at the 2008 Olympics. In Hayes, G. \& Karamichas, J. (eds) Olympic Games, mega-events and civil societies. Basingstoke: Palgrave Macmillan, pp.46-67.

Butler, B. \& Aicher, T. (2015) Demonstrations and displacement: social impact and the 2014 FIFA World Cup, Journal of Policy Research in Tourism, Leisure and Events, 7(3): 299-313.

Chalip, L. (2006) Towards social leverage of sports events. Journal of Sport \& Tourism, 11(2): 109-127.

Coalter, F. (2012) Sport-in-development: Accountability or development? In Levermore, R. \& Beacom, A (eds) Sport and international development. Basingstoke: Palgrave Macmillan, pp.55-75.

COHRE. (2007) Fair play for housing rights: Mega-events - Mega-events, Olympic Games and housing rights. Geneva: The Centre on Housing Rights and Evictions (COHRE). 
Cornelissen, S. (2012) A delicate balance: Major sports events and development. In Levermore, R. \& Beacom, A (eds) Sport and international development. Basingstoke: Palgrave Macmillan, pp.hig76-97.

Curi, M., Knijnik, J. \& Mascarenhas, G. (2011) The Pan American Games in Rio de Janeiro 2007: Consequences of a sport mega-event in a BRIC country. International Review for the Sociology of Sport, 46(2): 140-56.

Darcy, S. (2003) 'The politics of disability and access: The Sydney 2000 Games Experience', Disability and Society, 18(6): 737-757

Darnell, S.C. (2012) Sport for development and peace: A critical sociology. London: Bloomsbury.

Darnell, S.C. (2014) Orientalism through sport: towards a Said-ian analysis of imperialism and 'Sport for Development and Peace'. Sport in Society, 17(8): 1000-1014.

de Nooij, M., van den Berg, M., \& Koopmans, C. (2010) Bread or games? Social cost-benefit analysis of the World Cup in the Netherlands. Discussion paper No. 60: SEO Economic Research: Amsterdam [Online] Available from http://www.seo.nl/en/page/article/bread-orgames/ [Accessed 05/03/2011].

Dimeo, P. \& Kay, T. (2004) Major sports events, image projection and the problems of 'semiperiphery': a case study of the 1996 South Asia Cricket World Cup. Third World Quarterly, 25(7): 1263-1276.

Feddersen, A., Grotzinger, A., \& Maennig, W. (2009) Investment in stadia and regional economic development - evidence from FIFA World Cup 2006. International Journal of Sport Finance, 4(4): 221-239.

Finkel, R. (2015) Introduction: Social justice and events-related policy, Journal of Policy Research in Tourism, Leisure and Events, 7(3): 217-219.

Finlay, C., \& Xin, X. (2010) Public diplomacy games: a comparative study of American and Japanese responses to the interplay of nationalism, ideology and Chinese soft power strategies around the 2008 Beijing Olympics. Sport in Society, 13(5): 876-900.

Gratton, C., Dobson, N., \& Shibli, S. (2001) The role of major sports events in the economic regeneration of cities: lessons from six World or European Championships. In Gratton, C. \& Henry, I.P. (eds) Sport in the city: The role of sport in economic and social regeneration. London: Routledge: pp.35-45.

Grundlingh, A. (1998) From redemption to recidivism? Rugby and change in South Africa during the 1995 Rugby World Cup and its aftermath. Sporting Traditions, 14(2): 67-86.

Gupta, A. (2009) The globalisation of sports, the rise of non-western nations, and the impact on international sporting events. The International Journal of the History of Sport, 26(2): 17791790.

Hayes, G. and Karamichas, J. (eds) (2012) Olympic Games, mega-events and civil societies: Globalization, environment and resistance. Basingstoke: Palgrave. 
Hendricks, D.J. (2008) The impact of mega sports events on the social fabric of developing communities: Dreamfields: Exploiting the potential of the 2010 FIFA World Cup to impact positively on South African society. Paper presented at The impact of mega sports events on development goals international symposium. Stellenbosch 5-7 March, 2008 [Online] Available from http://www.toolkitsportdevelopment.org/mega-events/html/topic D10E0070-08F748E7-B574-498D57A7B49A 9A33E644-7384-443D-B1C2-D82F67865B35 1.htm [Accessed 22 July, 2011].

Horne, J. (2004) The global game of football: the 2002 World Cup and regional development in Japan. Third World Quarterly, 25(7): 1233-1244.

Hylton, K. \& Morpeth, N.D. (2012) London 2012: 'race' matters and the East End. International Journal of Sport Policy and Politics, 4: 1-18.

Jackson, R. (1990) Quasi-states: Sovereignty, international relations and the Third World. Cambridge: Cambridge University Press

Lake, D. (2008) The State and international relations. In Reus-Smit, C. \& Snidal, D. (eds) The Oxford handbook of international relations. Oxford: Oxford University Press, pp.41-61.

Lamond, I.R. \& Spracklen, K. (eds) (2014) Protests as events: Politics, activism and leisure. London: Roman \& Littlefield.

Levermore, R. (2004) Sport's role in constructing the "inter-state" worldview. In Levermore, R. \& Budd, A (eds) Sport and international relations: An emerging relationship? London: Routledge, pp.16-30.

Lindsay, I. (2014) London 2012: The rings of exclusion. In Dashper, K., Fletcher, T. \& McCullough, N.L. (eds) Sports events, society and culture. London: Routledge, pp.221-236.

Little, P. (1995) Ritual, power and ethnography at the Rio Earth Summit, Critique of Anthropology, 15(3): 256-83.

Maennig, W. \& Porche, M. (2008) The feel-good effect at mega sports events: Recommendations for public and private administration informed by the experience of the FIFA World Cup 2006. Hamburg Contemporary Economic Discussions, No. 18 [Online] Available from http://www.hced.uni-hamburg.de/WorkingPapers/018.pdf [Accessed 9 August, 2010].

Marinho, G., Campagnani, M., and Cosentino, R. (2014) 'Brazil', in de Paula, M and Bartlet, D. (eds) World Cup for whom and for what? A look upon the legacy of the world cups in Brazil, South Africa and Germany, Brasil: Henrich Boll Stiftung: 12-59 Matheson, V. \& Baade, R. (2004) Mega-sporting events in developing nations: Playing the way to prosperity? The South African Journal of Economics, 72(5): 1085-1095.

Media Tenor. (2010) WC 2010: Correct misconceptions? Pre-World Cup coverage of the host of WC 2010 (May). South Africa: Media Tenor.

Nauright, J. (2004) Global games: culture, political economy and sport in the globalised world of the 21st century. Third World Quarterly, 25(7): 1325-1336. 
Palmer, C. (2013) Global sports policy. London: Sage.

Rumford, C. (2007) More than a game: Globalization and the post-Westernization of world cricket. Global Networks. 7(2): 202-214.

Russell, K.A. and O'Connor, N. (2013) The London 2012 Olympic Games: The cultural tourist as a pillar of sustainability. In Raj, R., Griffin, K. \& Morpeth, N. (eds) Cultural tourism. Wallingford, UK: CABI, pp.204-211.

Schwengel, H. (2008) Emerging powers as fact and metaphor: Some European ideas. Futures, 40: 767-776.

Sharpley, R. and Stone, P. (2012) Socio-cultural impacts of events. In Page, S. \& Connell, J (eds) Routledge Handbook of Events. London: Routledge, pp.347-361.

Spears, I. (2004) States-within-States: An introduction to their empirical attributes. In Kingston, P. \& Spears, I. (eds) States-within-States: Incipient political entities in the post-Cold War era. New York: Palgrave Macmillan, pp.15-34.

Sturm, D. (2015). 'Fluid spectator-tourists': Innovative televisual technologies, global audiences and the 2015 Cricket World Cup'. Comunicazioni Sociali, 2: 230-240.

The Guardian. (2017) Rio's Olympic venues, six months on - in pictures [online] available from https://www.theguardian.com/sport/gallery/2017/feb/10/rios-olympic-venues-six-monthson-in-pictures [accessed 21 March, 2017].

Van de Walle, S. \& Scott, Z. (2011) The political role of service delivery in State-building: Exploring the relevance of European history for developing countries. Development Policy Review, 29(1): 5-21.

Whigham, S. (2013) 'Anyone but England'? Exploring anti-English sentiment as part of Scottish national identity in sport. International Review for the Sociology of Sport, 49(2): 152-174.

\footnotetext{
1 Despite the established nature of these concerns, reports from the most recently held events in Brazil, the 2014 men's Football World Cup and the 2016 Summer Olympic Games, suggest that an effective response to these concerns has yet to be established (cf. Marinho et al., 2014: 37-40). 2 The Sport and Rights Alliance (SRA) is a coalition of leading NGOs, sports organizations and trade unions. It was founded in early 2015 to address the decision-makers of international sports megaevents to introduce measures to ensure these events are always organized in a way that respects human rights (including labour rights), the environment and anti-corruption requirements at all stages of the process (for more information, visit:

http://www.sportandhumanrights.org/wordpress/index.php/2015/07/06/sport-and-rights-alliance/. ${ }_{3}$ See http://www.fifa.com/about-fifa/news/y=2015/m=7/news=fifa-executive-committee-setspresidential-election-for-26-february-20-2666448.html for more information.

4 Interviews with UK and international based sport reporters conducted by author A in 2010.

5 Outside of political organisations like the United Nations, the membership of international sports organisation is one of the few ways in which the status of statehood may be recognised. 6 In 2000 the FIFA Executive Committee voted for the men's World Cup tournament to be rotated from continent to continent. As from 2018, the hosting of the event will cease to be rotated.
} 